\title{
Eoarchean to Paleoproterozoic crustal evolution in the North China Craton
}

\author{
QIANG MA ${ }^{1,2}$, YI-GANG Xu'2, XIAO-LONG HUANGA ${ }^{2}$, \\ JIAN-PING ZHENG ${ }^{1}$ \\ ${ }^{1}$ School of Earth Sciences, State Key Laboratory of \\ Geological Processes and Mineral Resources, China \\ University of Geosciences, Wuhan 430074, China, \\ maqiang@cug.edu.cn and jpzheng@cug.edu.cn \\ ${ }^{2}$ State Key Laboratory of Isotope Geochemistry, Guangzhou \\ Institute of Geochemistry, Chinese Academy of Sciences, \\ Guangzhou 510640, China, yigangxu@gig.ac.cn and \\ xlhuang@gig.ac.cn
}

The early evolution of continental crust, particularly its lower layer, during the first 2.0 billion years of Earth history remains enigmatic. In our recernt paper, we present coupled in-situ $\mathrm{U}-\mathrm{Pb}, \mathrm{Lu}-\mathrm{Hf}$ and $\mathrm{O}$ isotope data for the Precambrian zircons from fourteen deep-crustal xenoliths from five localities in the North China craton. The results show that:

(1) Eo-Paleoarchean Xinyang granulite xenoliths are the oldest pieces of the crust in the southern NCC and perhaps the known oldest unexposed lower crustal rocks in the world, dating back to $\sim 3.82 \mathrm{Ga}$. The $3.82-3.55 \mathrm{Ga}$ magmatic zircons have predominant sub-chondritic $\mathrm{Hf}$ isotope compositions and elevated $\delta^{18} \mathrm{O}$ values, suggesting Lu-Hf fractionation and crust-hydrosphere interactions on the Earth can be traced back to Eoarchean or even earlier.

(2) The magmatic zircons from the studie xenoliths define four age populations at $3.82-3.55 \mathrm{Ga}, \sim 2.7 \mathrm{Ga}, \sim 2.5 \mathrm{Ga}$ and $1.95-1.85 \mathrm{Ga}$, and yield a non-linear $\mathrm{Hf}$ isotope-age array. These data reveal crustal growth in the North China occurred as early as $>3.9 \mathrm{Ga}$ and reached its climax in the Neoarchean. The pre-existing continental crust was reworked at 3.8-3.5 $\mathrm{Ga}, \sim 2.7 \mathrm{Ga}, \sim 2.5 \mathrm{Ga}$ and $1.95-1.85 \mathrm{Ga}$.

(3) The zircons from lower crustal xenoliths record a secular change in $\mathrm{O}$ isotopes. An increasing range in zircon $\delta^{18} \mathrm{O}$ values at $\sim 2.5 \mathrm{Ga}$ marks enhanced recycling of surfacederived materials, including high- $\delta^{18} \mathrm{O}$ sediments, weathered and altered rocks and low- $\delta^{18} \mathrm{O}$ altered oceanic crust. Subduction of hydrated oceanic crust back to mantle depths may have occurred at least before $\sim 2.5 \mathrm{Ga}$ and have played an important role in generation of continental crust.

Reference:

Ma Q., et al. Eoarchean to Paleoproterozoic crustal evolution in the North China Craton: Evidence from $\mathrm{U}-\mathrm{Pb}$ and $\mathrm{Hf}-\mathrm{O}$ isotopes of zircons from deep-crustal xenoliths. Geochimica et Cosmochimica Acta (in presss) https://doi.org/10.1016/j.gca.2019.09.009. 